\title{
HUMAN REPRODUCTIVE DECISIONS
}




\section{THE GALTON INSTITUTE}

The Galton Institute is concerned with the interdisciplinary study of the biological, genetic, economic, social and cultural factors relating to human reproduction, development and health in the broadest sense. The Institute has a wide range of interests which include the description and measurement of human qualities, human heredity, the influence of environment and the causes of disease, genetic counselling, the family unit, marriage guidance, birth control, differential fertility, infecundity, artificial insemination, termination of pregnancy, population problems and migration. As a registered charity, the Institute does not propagate particular political views, but it does seek to foster respect for human variety and to encourage circumstances in which the fullest achievement of individual human potential can be realised. More generally, the Institute seeks to advance understanding of biosocial matters by enabling biologists, clinicians, demographers, sociologists and other professionals to work together in a mutually productive manner.

The Galton Institute was formed in 1988 as the successor body to the Eugenics Society, which in turn derived from the Eugenics Education Society founded in 1907 by Sir Francis Galton, FRS. Membership of the Institute is international and consists of fellows and members. Fellows are those who contribute by their work and writings to the advancement of knowledge in the biosocial sciences. Members are drawn from a wide area of biosocial interests. Amongst its activities the Institute supports original research via its Stopes Research Fund, sponsors the annual Darwin Lecture in Human Biology, co-sponsors the biennial Caradog Jones Lecture, and publishes the journal Biology and Society. Each year, the Institute mounts a two-day symposium in which a topic of current importance is explored from differing standpoints, and during which the Galton Lecture is delivered by a distinguished guest.

Information about the Institute, its aims, activities and publications may be obtained from: The General Secretary, The Galton Institute, 19 Northfields Prospect, Northfields, London SW18 1FE, England. 


\section{Human Reproductive Decisions}

\section{Biological and Social Perspectives}

Proceedings of the Thirtieth Annual Symposium of the Galton Institute, London, 1993

Edited by

R. I. M. Dunbar

Professor of Psychology

University of Liverpool 
ISBN 978-1-349-23949-8 ISBN 978-1-349-23947-4 (eBook)

DOI 10.1007/978-1-349-23947-4

(c) The Galton Institute 1995

Softcover reprint of the hardcover 1st edition 1995 978-0-333-62051-9

All rights reserved. No reproduction, copy or transmission of this publication may be made without written permission.

No paragraph of this publication may be reproduced, copied or transmitted save with written permission or in accordance with the provisions of the Copyright, Designs and Patents Act 1988, or under the terms of any licence permitting limited copying issued by the Copyright Licensing Agency, 90 Tottenham Court Road, London WIP 9HE.

Any person who does any unauthorised act in relation to this publication may be liable to criminal prosecution and civil claims for damages.

First published in Great Britain 1995 by

MACMILLAN PRESS LTD

Houndmills, Basingstoke, Hampshire RG21 2XS

and London

Companies and representatives

throughout the world

This book is published in Macmillan's Studies in Biology, Economy and Society series

General Editor: Robert Chester

A catalogue record for this book is available

from the British Library.

ISBN 978-0-333-62051-9

$\begin{array}{rrrrrrrrrr}10 & 9 & 8 & 7 & 6 & 5 & 4 & 3 & 2 & 1\end{array}$

$\begin{array}{llllllllll}04 & 03 & 02 & 01 & 00 & 99 & 98 & 97 & 96 & 95\end{array}$

First published in the United States of America 1995 by

Scholarly and Reference Division,

ST. MARTIN'S PRESS, INC.,

175 Fifth Avenue,

New York, N.Y. 10010

ISBN 978-0-312-12436-6

Library of Congress Cataloging-in-Publication Data

Galton Institute (London, England). Symposium (30th : 1993 : London,

England)

Human reproductive decisions : biological and social perspectives

: proceedings of the thirtieth annual symposium of the Galton

Institute, London, 1993 / edited by R. I. M. Dunbar.

p. $\mathbf{c m}$.

Includes index.

ISBN 978-0-312-12436-6

1. Human reproduction. 2. Fertility-Human. 3. Birth control.

I. Dunbar, R. I. M. (Robin Ian McDonald), 1947- . II. Title.

GN235.G35 1995

304.6'32-dc20 


\section{Contents}

List of Tables

vii

List of Figures

viii

Notes on the Contributors

$\mathrm{xi}$

1 An Interdisciplinary Approach to Human Fertility

1

R. I. M. Dunbar

2 Breastfeeding and the Baby: Natural Contraception

Alan S. McNeilly

3 Understanding Natural Variation in Human Ovarian Function

22

Peter T. Ellison

4 Nutrition, Physical Workloads and Fertility Regulation

Lyliane Rosetta

5 For Love or Money: the Evolution of Reproductive and Material Motivations

Alan R. Rogers

6 Fertility and Fitness Among Albuquerque Men: a

Competitive Labour Market Theory

Hillard S. Kaplan, Jane B. Lancaster,

John A. Bock and Sara E. Johnson

7 Reproductive Decisions Viewed from an Evolutionarily Informed Historical Demography

Eckart Voland

8 English Fertility, 1600-1900: Is an Economic Analysis Tenable? 160 P. R. Andrew Hinde

9 Stopping, Starting and Spacing: the Regulation of Fertility in Historical Populations

John Landers 
10 Obstacles to Fertility Decline in Developing Countries

11 Imperatives to Reproduce: Views from North-west

England on Fertility in the Light of Infertility

Jeanette Edwards

12 The Timing of Childbearing in Developed Countries

Máire Ní Bhrolcháin

13 Low Fertility in a Pastoral Population: Constraints or Choice?

279

Sara Randall

Index 


\section{List of Tables}

3.1 Salivary progesterone levels across seven 5-year age groups in three populations (Boston, Lese, Tamang)

6.1 The sample of Albuquerque men by birth cohort

6.2 Regression models of number of grandchildren on predictor variables

6.3 Reduced regression model of effects of parental investment on income

7.1 Measures of average lifetime reproductive success of the 60 wealthiest men of Krummhörn and the contemporary population mean

7.2 Mean number of adult children in the local population by female age at marriage and male land ownership

9.1 Cumulative age-specific marital fertility per woman

9.2 Estimates of mean fecundability in historical populations 189

9.3 Estimates of non-susceptible period

9.4 Percentage single by age-group in selected countries around 1900

9.5 Persons per 100 households by relationship to head - rural Denmark and rural India

9.6 Servants as a percentage of total population by age

10.1 Life expectancy at birth and infant mortality at onset of fertility decline

12.1 Median age at first birth by birth cohort 259

12.2 Median age at last birth by birth cohort 260

12.3 Parity progression ratios by birth cohort 261

12.4 Median time from first to last birth by birth cohort 263

12.5 Estimates of birth intervals 265

13.1 Marriage indices for Kel Tamasheq and Bambara 282

13.2 Numbers of Bambara and Tamasheq women by marriage category

13.3 Progression to motherhood (pp0): iklan and illelan 


\section{List of Figures}

2.1 Components of the interbirth interval

3.1 An example profile of salivary oestradiol and progesterone from a single subject aligned on menstrual onset

3.2 The continuum of ovarian function

3.3 Salivary progesterone profiles for six consecutive cycles for two different individuals

3.4 Mean values by age group for four indices of ovarian function from 126 Boston women

3.5 Average profiles of salivary oestradiol in 53 Boston women by age group

3.6 Best-fit quadratic regressions of mid-luteal salivary progesterone on age in three populations: middle-class Boston women, Lese horticulturalists from Zaïre and Tamang agro-pastoralists from Nepal.

3.7 Ovulatory frequency by month among Lese women in 1984 , assessed from salivary progesterone profiles

3.8 Mean values for ovulatory frequency, days of menstrual flow, weight and cycle length for Lese women by month in 1989

3.9 Monthly distributions of conceptions (birth dates minus 9 months) for Lese women between January and August 1987

3.10 Average salivary progesterone profiles by season for Tamang women in 1990-1.

3.11 Average salivary progesterone profiles for 20 rural Polish farm women categorised by the intensity of their subsistence workloads

3.12 Average salivary progesterone profiles for women from four populations: middle-class Boston women, Quechua Indians of highland Bolivia, Lese horticulturalists from Zaïre and Tamang agro-pastoralists from Nepal

5.1 An evolutionary equilibrium under clonal inheritance

5.2 Number of offspring gained for given investments of wealth

5.3 An optimal strategy with $\gamma>0$

5.4 An optimal strategy with $\gamma=1$ 
5.5 Response of $r_{\text {kids }}$ and $r_{\text {wealth }}$ to $s$ and $\beta$ for $\gamma=0 \quad 91$

5.6 Response of $r_{\text {kids }}$ and $r_{\text {wcalth }}$ to $s$ and $\beta$ for $\gamma=1$

$5.7 r_{\text {kids }}$ and $r_{\text {wealth }}$ against $\lambda \quad 93$

6.1 Direct and indirect effects of fertility on fitness 98

$\begin{array}{lll}6.2 & \text { Factors that influence fertility } & 100\end{array}$

6.3 Ethnic distribution of men in sample obtaining drivers licenses versus frequencies for Albuquerque SMSA 103

6.4 Completed fertility by 5-year cohort 104

6.5 Age at first birth by 5-year cohort 106

6.6 Reproductive lifespan by 5-year cohort 108

6.7 Frequency distribution of completed fertility for Anglo men

6.8 Frequency distribution of completed fertility for Hispanic men

6.9 Phenotypic variation in optimum fertility 113

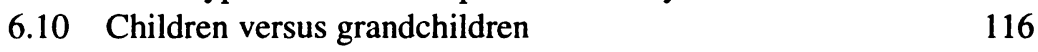

6.11 Father's children versus ego's children 117

6.12 Completed fertility by income for Anglo men 119

6.13 Completed fertility by income for Hispanic men 122

6.14 The determinants of fitness 126

7.1 Ratio of farmers' fitness to the overall population mean (Krummhörn, marriage cohort, 1720-50)

7.2 Mean age for men and women (first marriages only) by land ownership of the men (Krummhörn, 1720-1874)

7.3 Mean number of godparents for children surviving or not surviving their first year of life

7.4 Male infant mortality by social group and number of living brothers (Krummhörn, 1720-1874)

7.5 Female infant mortality by social group and number of living sisters (Krummhörn, 1720-1874)

7.6 Infant mortality (first born children only) by sex and social group (Leezen, 1720-1869)

7.7 Ratio of sex-typical infant mortality $\left(q_{i} / q_{m}\right)$ in the upper and lower classes of five north German populations, arranged according to their mean population increase

7.8 Trivers/Willard effect (T/W) in five north German populations

9.1 Percentage distribution of provinces of Europe by the pre-decline plateau of $I_{g}$

9.2 Index of proportions married $\left(I_{m}\right)$ in European provinces in 1990 
10.1 Trends in total fertility: major developing regions, 1960-1990

10.2 Scatterplot of Indian states, by level of female literacy and total fertility

10.3 Total fertility rate by country, 1990

10.4 Rural total fertility rates by educational level of women, selected states of India, 1984

12.1 Period mean age at maternity, standardised, European countries, 1951-91

12.2 Standard deviation of age at maternity, European countries, 1951-91

12.3 Period mean age: all and first births, England and Wales, standardised

12.4 Standard deviation of age at all and first births, England and Wales, standardised

12.5 Median age at first and last birth, birth cohorts, 1911-48 255

12.6 Median time between first and last birth, birth cohorts, 1911-48

12.7 Standard deviation of span of childbearing, birth cohorts, 1911-48

12.8 Estimated median second interval, England and Wales and Great Britain, 1910-91

12.9 Estimated median third interval, England and Wales and Great Britain, 1910-91

13.1 Parity progression ratios

13.2 Parity progression ratios by age, marital status and ethnicity

13.3 Tamasheq social class PPRs

13.4 PPRs for iklan and illelan, widowed and divorced women aged 20-34 


\section{Notes on the Contributors}

John A. Bock, Department of Anthropology, University of New Mexico, Albuquerque, New Mexico, USA.

John Cleland, Population Studies Unit, London School of Hygiene and Tropical Medicine.

R. I. M. Dunbar, Department of Psychology, University of Liverpool.

Jeanette Edwards, Department of Anthropology, University of Manchester.

Peter T. Ellison, Department of Anthropology, Harvard University, Cambridge, Massachusetts, MA, USA.

P. R. Andrew Hinde, Department of Social Statistics, University of Southampton.

Sara E. Johnson, Department of Anthropology, University of New Mexico, Albuquerque, New Mexico, USA.

Hillard S. Kaplan, Department of Anthropology, University of New Mexico, Albuquerque, New Mexico, USA.

Jane B. Lancaster, Department of Anthropology, University of New Mexico, Albuquerque, New Mexico, USA.

John Landers, All Souls College, Oxford.

Alan S. McNeilly, MRC Reproductive Biology Unit, Centre for Reproductive Biology, Edinburgh.

Máire Ní Bhrolcháin, Department of Social Statistics, University of Southampton.

Sara Randall, Department of Anthropology, University College, London. 
xii

Notes on the Contributors

Alan R. Rogers, Department of Anthropology, University of Utah, Salt Lake City, Utah, USA.

Lyliane Rosetta, Department of Biological Anthropology, University of Cambridge.

Eckart Voland, Department of Anthropology, University College, London. 